\title{
Spiroplasma citri Movement into the Intestines and Salivary Glands of Its Leafhopper Vector, Circulifer tenellus
}

\author{
Myoung-Ok Kwon, Astri C. Wayadande, and Jacqueline Fletcher
}

Department of Entomology and Plant Pathology, 127 Noble Research Center, Oklahoma State University, Stillwater 74078. Accepted for publication 11 August 1999.

\begin{abstract}
Kwon, M.-O., Wayadande, A. C., and Fletcher, J. 1999. Spiroplasma citri movement into the intestines and salivary glands of its leafhopper vector, Circulifer tenellus. Phytopathology 89:1144-1151.

Spiroplasma citri, a helical, wall-less prokaryote in the class Mollicutes, is transmitted by the beet leafhopper, Circulifer tenellus. Invasion of leafhopper tissues and cytopathological effects by $S$. citri were investigated by transmission electron microscopy. All eight cell types of the principle salivary glands, as well as the adjacent muscle cells and the cells of the accessory salivary glands, were colonized by the spiroplasmas. In both midgut epithelia and salivary gland cells, spiroplasmas usually occurred in membrane-bound cytoplasmic vesicles that often were

by invagination of the plasmalemma beneath intact basal lamina. These observations are consistent with spiroplasma entry into the insect cells by receptor-mediated endocytosis. Cytopathological effects of spiroplasma infection in salivary cells included loss of membrane and basal lamina integrity, presence in some cells of irregular inclusion-like structures containing dense matrices of filamentous material that labeled with anti$S$. citri antibodies, and apparent disorganization of the endoplasmic reticulum. Compared to the tightly aligned fiber bundles in healthy muscle cells, bundles in spiroplasma-containing muscle cells appeared fragmented and loosely arranged. Such symptoms could contribute to the reduction in longevity and fecundity that has been previously reported for S. citri-infected C. tenellus.
\end{abstract} located near the cell periphery. In several salivary gland cells, spiroplasmas were also observed within membranous pockets apparently formed

The mollicute Spiroplasma citri (Mycoplasmatales: Spiroplasmataceae), a wall-less prokaryote with helical morphology, is an important pathogen worldwide, causing citrus stubborn disease (14) and brittle root disease of horseradish (4). The pathogen inhabits the phloem of its plant hosts, causing symptoms indicative of phloem dysfunction. In the United States, S. citri is transmitted in a propagative manner by the beet leafhopper, Circulifer tenellus Baker (12). Leafhoppers ingest spiroplasmas during phloem feeding and transport them to new host plants. For transmission to occur, spiroplasmas must infect gut epithelial cells, where they multiply before crossing into the hemocoel. Spiroplasmas continue to multiply in the hemolymph and then migrate to other organs, such as the brain and Malphigian tubules (8). They eventually invade the salivary glands (12), from which they are subsequently deposited in the phloem of a new host plant via salivary secretions during feeding.

Cellular barriers play an important role in transmission of spiroplasmas, phytoplasmas, and persistently transmitted plant viruses. The mechanisms involved in the passage of luteoviruses through the intestinal and salivary gland cells of their aphid vectors have been well characterized. These viruses enter the hindgut epithelial cells of the insect by receptor-mediated endocytosis (5) and traverse the basal plasmalemma to enter the hemolymph. The accessory salivary gland basal lamina has a high specificity for specific virus capsid-glycoprotein interactions that apparently regulate basal lamina penetration and determine specificity of the transmission process (6). However, luteoviruses do not invade cells of the aphid principal salivary glands. Phytoplasmas, nonhelical phytopathogenic mollicutes, resemble their helical spiroplasma relatives in that they are leafhopper transmitted. Lefol et al. (10) sug-

Corresponding author: A. C. Wayadande; E-mail address: astri@ okstate.edu

Publication no. P-1999-1004-02R

(C) 1999 The American Phytopathological Society
Additional keywords: adhesion, disease transmission. gested that the phytoplasmas causing flavescence doreé (FD) are able to multiply in the intestinal lumen of the vector leafhopper, Euscelidius variegatus, and attach to specific receptor sites in the midgut before moving into gut cells. The authors also suggested that some FD phytoplasmas migrate directly between intestinal cells from the lumen to the hemolymph (a process called diacytosis). The mechanism of invasion of the C. tenellus salivary glands by $S$. citri also has been investigated. Liu (11) reported that spiroplasmas penetrate through the plasmalemma of intestinal epithelial cells into the cytoplasm and move toward the basal membrane of the cell via the endoplasmic reticulum, which connects the inner and outer boundaries of the epithelial cells. However, Alivizatos and Markham (1), observing spiroplasmas in the intercellular spaces between salivary gland cells, suggested that spiroplasmas enter salivary glands by diacytosis. Thus, the mechanism of spiroplasma entry and traversal of vector cells remains unclear.

Numerous insect species harbor spiroplasmas, but whether the association is pathogenic or symbiotic is not known in most cases (9). Pathogenicity of mollicutes toward their vectors is usually associated with reduced insect longevity and fecundity, but the underlying causes of these effects are not well understood. In $S$. taiwanense-infected mosquitoes, Anopheles stephensi, histopathology of muscle cells includes necrosis, disruption of the cell membrane, splitting of myofibrils, condensation, swelling, and lysis of mitochondria. Loss of the Z-disk and intercellular replication of spiroplasmas in the thoracic flight muscles of these mosquitoes results in the loss of flight capacity (17). Vectors of plant pathogenic spiroplasmas may or may not be adversely affected by these pathogens. S. kunkelii, the corn stunt spiroplasma, is mildly pathogenic to its vector, Dalbulus maidis (13), but may increase survival for overwintering females (3). S. citri-infected beet leafhoppers die prematurely after injection, membrane feeding, or feeding on $S$. citri-infected plants (11), but the same spiroplasma has little effect on the longevity of the experimental $S$. citri vector leafhopper, Euscelis plebejus, which transmits European yellows 
type pathogens (18). Cultured S. citri is also pathogenic to the aster leafhopper, Macrosteles fascifrons, the major vector of the aster yellows phytoplasma (23) and an experimental vector of $S$. citri (16). In this article, we describe the mode of entry and cytopathology of $S$. citri in the leafhopper vector, C. tenellus.

\section{MATERIALS AND METHODS}

Origin of spiroplasmas. $S$. citri strain BR3 was isolated originally from horseradish plants with brittle root disease (4) and singlecell cloned three times (BR3-3X). S. citri line BR3-T1 was single-cell cloned three times from $S$. citri BR3-T, which is an insect-transmissible line of BR3-3X obtained by long-term maintenance of the spiroplasma in turnip plants via its natural vector, $C$. tenellus. Cultures of BR3-T1 were initiated from frozen aliquots and grown to log phase in LD8 broth medium (2). Bacterial titer was determined by direct counts using dark-field microscopy.

Leafhoppers. Healthy colonies of $C$. tenellus, originally started by C. E. Eastman (4) from individuals collected in Illinois, were reared on sugar beet plants, Beta vulgaris (a S. citri nonhost). The insects were housed in organdy-covered cages held at $25^{\circ} \mathrm{C}$ with a photoperiod of $14 \mathrm{~h}$ light, $10 \mathrm{~h}$ dark. S. citri-exposed individuals were housed in a separate facility with similar temperature and photoperiod conditions.
$S$. citri acquisition. Healthy $C$. tenellus late instar nymphs were placed on $S$. citri-infected turnip plants for a 4-day acquisition access period (AAP). After a 5-week incubation period on sugar beet plants, hemolymph was sampled from individual insects by severing a leg and collecting approximately $0.05 \mu \mathrm{l}$ of hemolymph from the wound in a $0.5-\mu \mathrm{l}$ capacity glass capillary tube (Drummond Scientific, Broomall, PA). The hemolymph was added to 2 $\mathrm{ml}$ of antibiotic medium 9 (20) and incubated at $31^{\circ} \mathrm{C}$. Culture tubes were examined for the presence of spiroplasmas using darkfield microscopy every 2 days for 3 weeks. Leafhoppers shown in this manner to have harbored spiroplasmas in their hemolymph were processed for electron microscopy.

In other experiments, leafhoppers were injected with cultured $S$. citri. Adult or late instar nymphs of healthy $C$. tenellus leafhoppers were aspirated onto a vacuum stage (a Parafilm-sealed petri dish with a $2-\mathrm{mm}^{2}$ hole covered with fine-mesh nylon, attached by plastic tubing [ $0.5 \mathrm{~cm}$ in diameter] to a vacuum source), and positioned ventral side up. Using a heat-drawn glass needle, $0.02 \mu \mathrm{l}$ (200 cells) of a log phase $\left(10^{8}\right.$ spiroplasmas per $\left.\mathrm{ml}\right)$ culture was injected into the hemocoel through the intersegmental membrane between abdominal segments 2 and 4 . To identify inoculative insects, leafhoppers were caged with sugar beet plants for 14 days in an insectary. Surviving leafhoppers were placed one per plant on four-leaf turnip (Brassica rapa L.) seedlings, a susceptible host
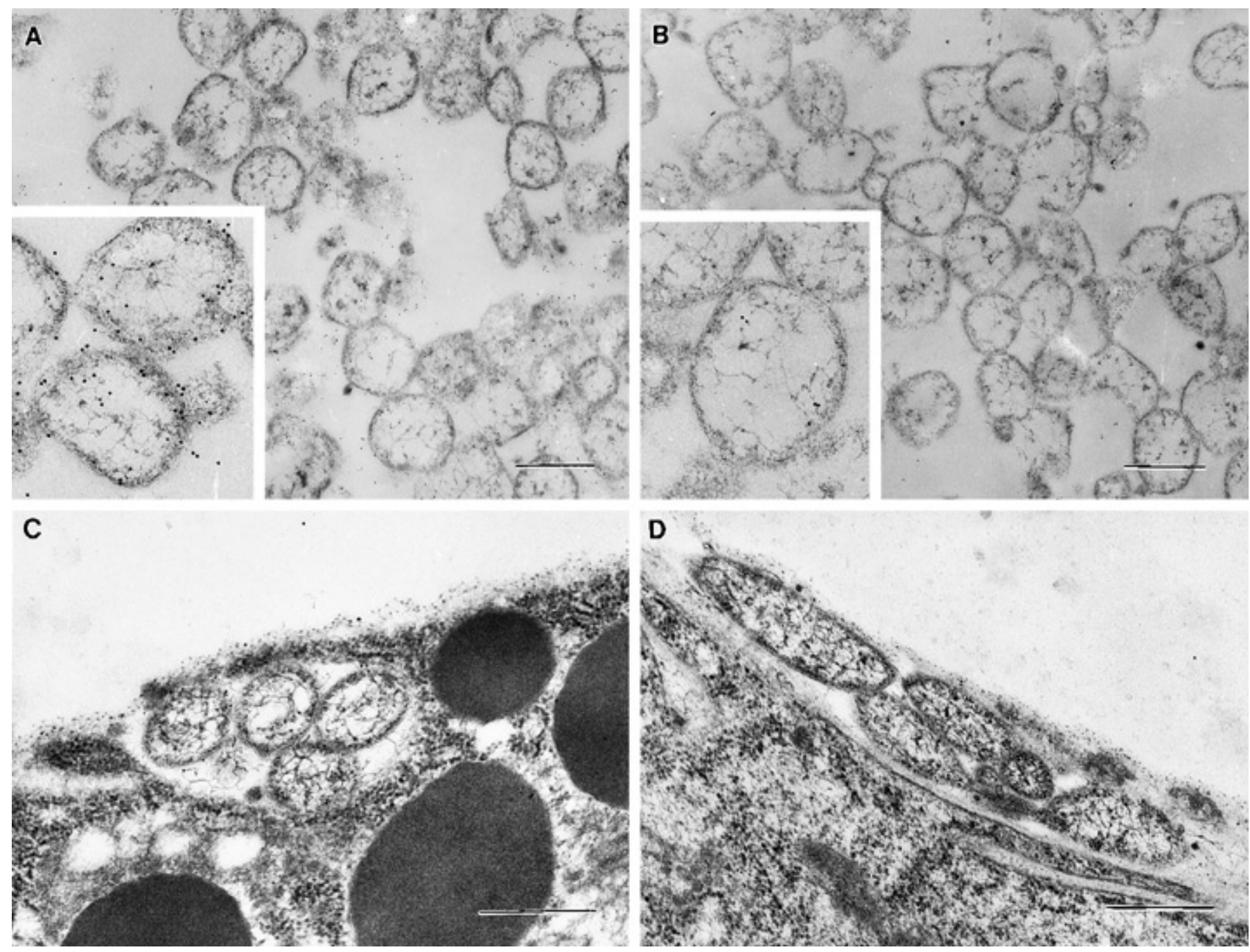

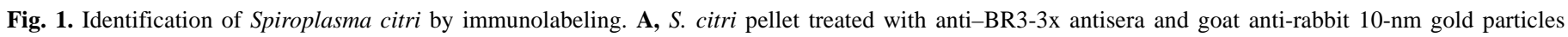

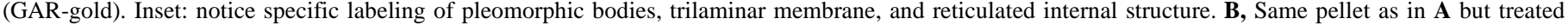

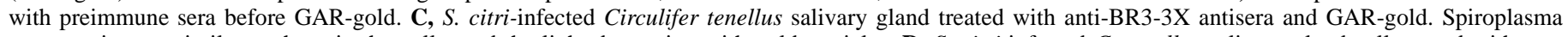

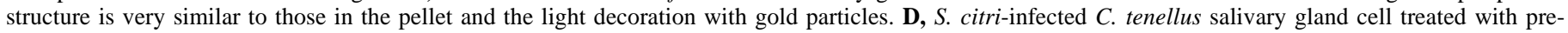
immune sera and GAR-gold. There is lack of significant decoration of spiroplasmas. Bars $=0.5 \mu \mathrm{m}$. 
plant, for a 3-day inoculation access period (IAP). Leafhoppers were removed and processed for electron microscopy. Test plants were housed in a greenhouse for expression of symptoms, which usually appeared within 14 days. Leafhoppers that had transmitted $S$. citri to turnip seedlings were examined by transmission electron microscopy.

Tissue processing. After the IAP, leafhopper heads were gently teased away from the body while immersed in $2.5 \%$ glutaraldehyde in $0.1 \mathrm{M}$ cacodylate buffer, $\mathrm{pH} 7.4$, and placed into the same fixative for 48 to $72 \mathrm{~h}$ at $4^{\circ} \mathrm{C}$. Intact guts were obtained from decapitated leafhoppers by gripping the lower end of the abdomen with forceps and gently pulling it and the viscera away from the body. The samples were rinsed in $0.1 \mathrm{M}$ sodium cacodylate buffer, postfixed for $2 \mathrm{~h}$ in $1 \%$ osmium tetroxide, rinsed again in cacodylate buffer, dehydrated in a graded ethanol series, washed three times in $100 \%$ propylene oxide, and infiltrated in 1:1 propylene oxide/Polybed 812 medium (Polysciences Inc., Warrington, PA) overnight at room temperature. The propylene oxide was allowed to evaporate for $8 \mathrm{~h}$ and the tissues were embedded in fresh Polybed medium for $48 \mathrm{~h}$ at $60^{\circ} \mathrm{C}$. Four $S$. citri-infected and four healthy leafhopper samples were examined in this study.

Immunolabeling of infected leafhoppers. For immunolabeling, tissues were fixed with $4 \%$ paraformaldehyde and $0.2 \%$ glutaraldehyde in $0.1 \mathrm{M}$ cacodylate buffer. After dehydration, the tissues were infiltrated in LR gold resin (London Resin Co. Ltd., Berkshire, England) without accelerator and, after $24 \mathrm{~h}$, infiltrated in LR gold resin with $0.3 \%$ benzoin methyl ether accelerator at $0^{\circ} \mathrm{C}$, and embedded in fresh LR gold resin with $0.3 \%$ accelerator using $\mathrm{UV}$ light for $18 \mathrm{~h}$ at $-21^{\circ} \mathrm{C}$. After transmission of $S$. citri to plants was confirmed for specific leafhoppers, those insect samples were serially thin-sectioned (80 to $90 \mathrm{~nm}$ ) using a Sorvall MT6000 ultramicrotome (DuPont de Nemours Inc., Wilmington, DE). Thin sections were collected on 200-mesh nickel grids, poststained with $5 \%$ uranyl acetate and lead citrate, and examined using a 100-CX scanning transmission electron microscope (JEOL, Tokyo) operated at $80 \mathrm{kV}$. To positively identify spiroplasmas in insect tissues, spiroplasma of infected and healthy control leafhopper salivary glands were immunolabeled with $10 \mathrm{~nm}$ of gold (Sigma-Aldrich, St. Louis; 22). Sections were blocked at room temperature for $2 \mathrm{~h}$ using $5 \%$ fetal bovine serum (FBS) in $0.1 \mathrm{M}$ phosphate-buffered saline (PBS) containing 5\% glycine (FBS-PBS-GLY). They were subsequently incubated at room temperature for $1 \mathrm{~h}$ on drops of polyclonal antisera specific for whole cells of BR3-3X, or for $S$. citri protein P29 (spiralin, the major membrane antigen), or preimmune serum, diluted 1:10 in FBS-PBS-GLY. After rinsing 10 times with FBS-PBS-GLY, grids were incubated at room temperature for $2 \mathrm{~h}$ on drops of goat anti-rabbit gold conjugate (SigmaAldrich) diluted 1:15 in FBS-PBS-GLY. Grids were rinsed again and fixed with $2 \%$ glutaraldehyde. After rinsing, grids were counterstained with uranyl acetate and lead citrate as above. Sections were examined with a 100-CX STEM at $80 \mathrm{kV}$.

\section{RESULTS}

Identification of spiroplasmas. Spiroplasmas in infected insects were identified based on their size and morphology and on the presence of DNA-like strands and a trilaminar plasmalemma. In vivo, spiroplasmas were not helical but are instead rounded or pleomorphic with reticulated internal structure. Our ability to correctly identify $S$. citri in this manner was confirmed by immunolabeling both spiroplasma pellets and in situ spiroplasmas with BR3-3X anti-S. citri antibodies. Spiroplasma-like bodies were not observed in healthy insects. The pleomorphic spiroplasmas ranged in size from 0.3 to $0.5 \mu \mathrm{m}$ in diameter (Fig. 1) and were decorated with gold particles in immunolabeled sections (Fig. 1A and C).

Distribution of $S$. citri in infected leafhoppers. Spiroplasmas occasionally were observed in the gut lumen among the gut-inhabiting bacteria that normally inhabit $C$. tenellus in our colony. These spiroplasmas were pleomorphic with poorly defined membranes. On two occasions, we observed spiroplasmas apparently fixed while moving into the gut epithelial cell from the gut lumen (Fig. 2A). There was no clear demarcation between the spiroplasma membrane and the midgut apical plasmalemma in these micrographs, but other micrographs clearly show spiroplasmas in membrane bound vesicles within the cytoplasm (Fig. 2B). These vesicles were most frequently observed at the cell periphery, near the basal plasmalemma. Spiroplasmas also were observed in muscle cells that surround the gut but not in the spaces between the basal plasmalemma and basal lamina of gut cells.
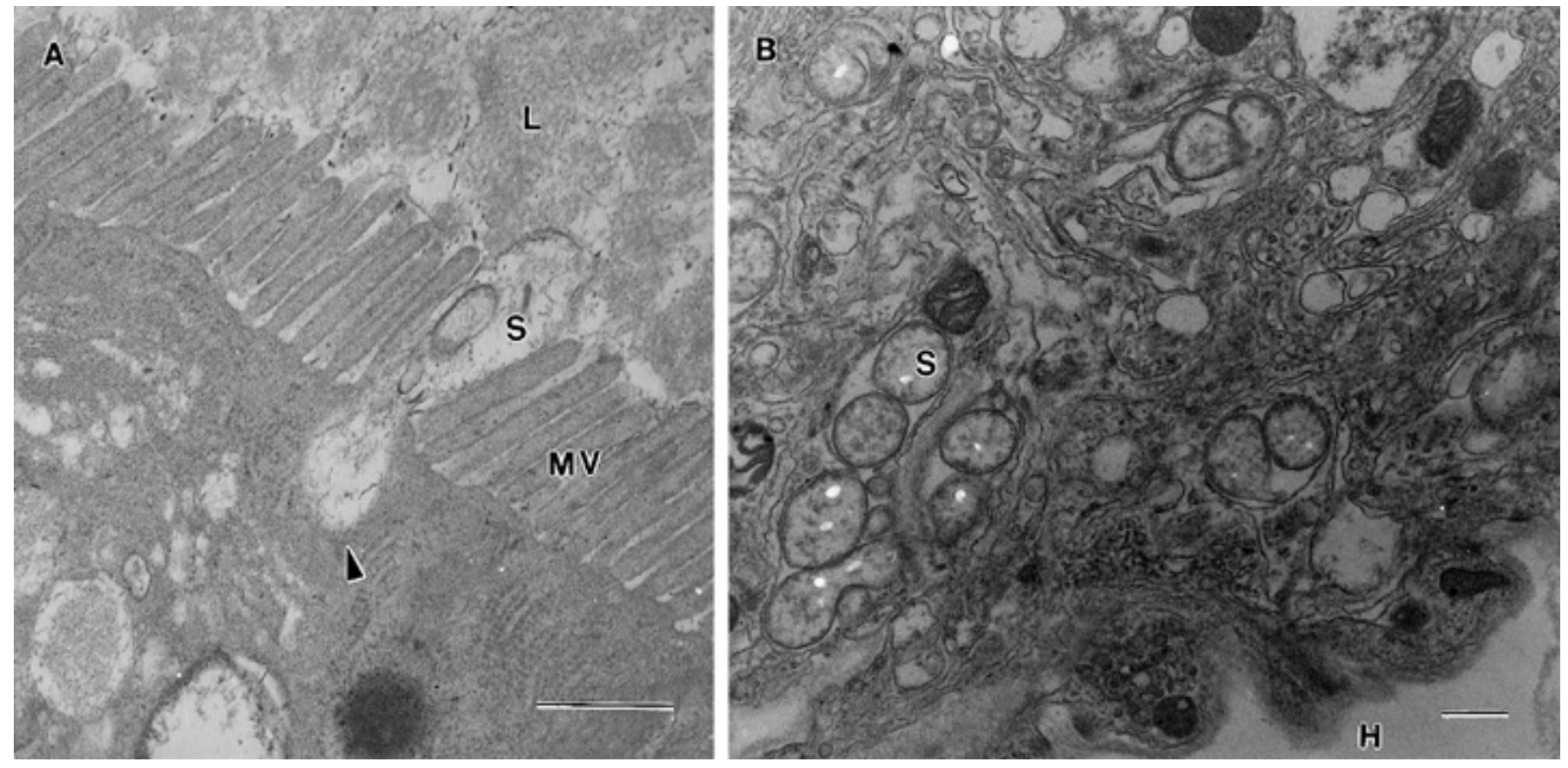

Fig. 2. Gut epithelial cells of Spiroplasma citri-infected Circulifer tenellus. A, Spiroplasma apparently entering gut cell between microvilli. Part of the trilaminar membrane is visible (arrow). $\mathrm{L}=$ gut lumen, $\mathrm{MV}=$ microvilli. B, Area near the basal plasmalemma showing spiroplasmas in membrane-bound pockets. $\mathrm{S}=$ spiroplasma, $\mathrm{H}=$ hemocoel. Bars $=0.5 \mu \mathrm{m}$. 
Spiroplasmas were detected in representative cells of each of the eight salivary gland cell types (19) and in the accessory glands of infected $C$. tenellus but were not seen in any cells of the control insects. Spiroplasmas were more common in cell types I, II, IV,
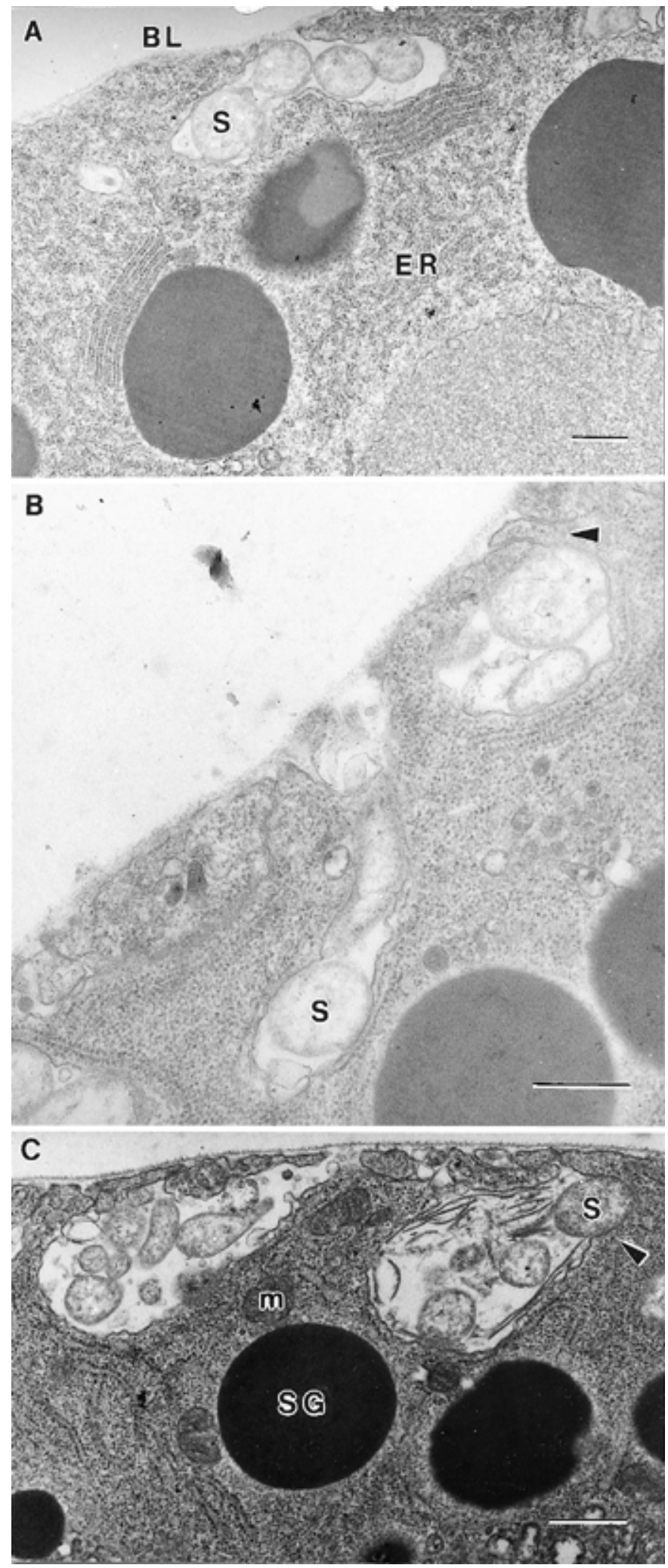

Fig. 3. Salivary gland cells of Spiroplasma citri-infected Circulifer tenellus. A, Spiroplasmas in a membrane-bound pocket of the cell plasmalemma. B, Spiroplasmas in deep invaginations of the gland cell plasmalemma. Plasmalemma contain finger-like extensions (arrow). C, Spiroplasmas in invaginated pockets of cell plasmalemma. There is close contact between a spiroplasma and the plasmalemma (arrow). $\mathrm{S}=$ spiroplasma, $\mathrm{SG}=$ secretory granule, $\mathrm{ER}=$ endoplasmic reticulum, $\mathrm{m}=$ mitochondrion, $\mathrm{BL}=$ basal lamina. $\mathrm{Bars}=0.5 \mu \mathrm{m}$. and VIII than in other types. They occurred either singly or in colonies of up to 20 , within membrane-bound cytoplasmic vesicles located either in the interior or near the periphery of the cell cytoplasm (Fig. 3A through C). Occasionally, in cell types IV, VI, and VII, some spiroplasmas appeared to be free in the host cell cytoplasm rather than contained within a membrane-bound vesicle. In four separate fields of view, spiroplasmas were found inside the canaliculi, which ramify through the salivary gland cells (Fig. 4). Spiro-

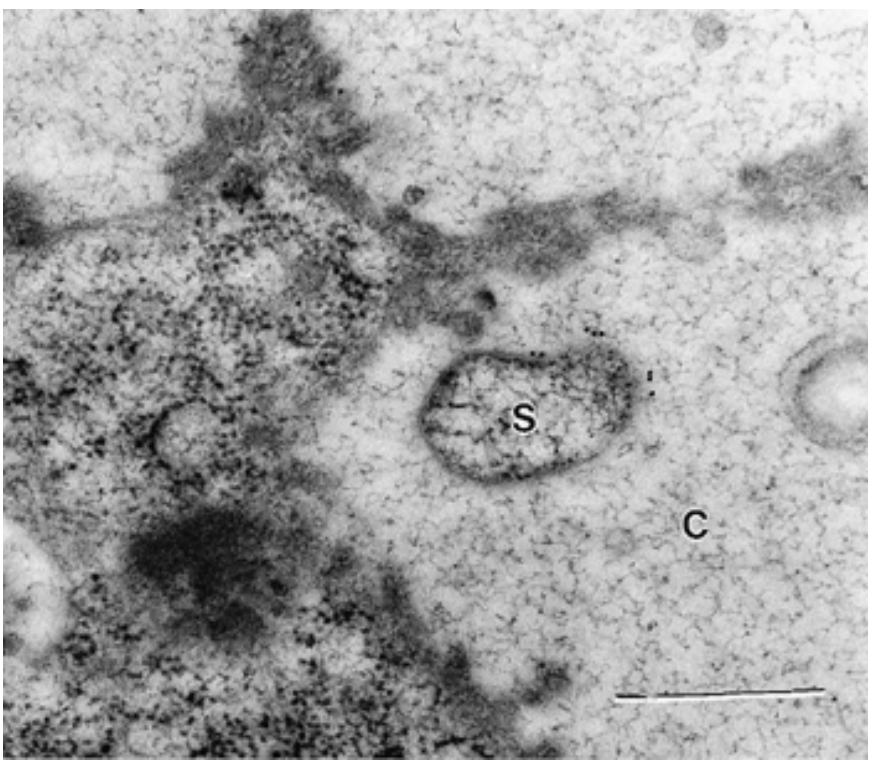

Fig. 4. A single spiroplasma treated with anti-BR3-3X antisera and goat antirabbit $10-\mathrm{nm}$ gold particles located in the canaliculus of a salivary gland cell of Circulifer tenellus. $\mathrm{S}=$ spiroplasma, $\mathrm{C}=$ canaliculus. $\mathrm{Bar}=0.5 \mu \mathrm{m}$.

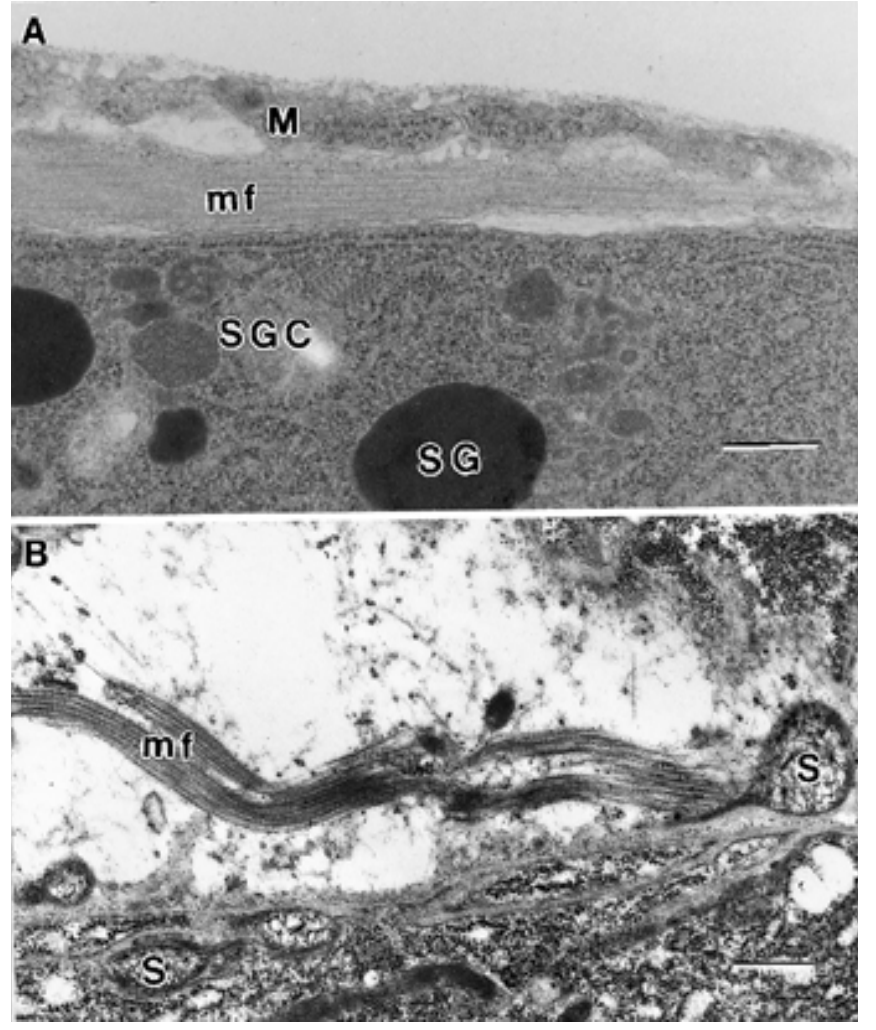

Fig. 5. Muscle fibers in Circulifer tenellus salivary glands. A, Muscle cell from a healthy C. tenellus leafhopper. B, Muscle cell from a Spiroplasma citriinfected leafhopper. Fibers are poorly aligned, and the cytoplasmic space is empty. Spiroplasmas also are present in the junction between the muscle cell and salivary gland cell. $\mathrm{S}=$ spiroplasma, $\mathrm{M}=$ muscle cell, $\mathrm{SG}=$ secretory granule, $\mathrm{SGC}=$ salivary gland cell, $\mathrm{mf}=$ muscle fibers. Bars $=0.5 \mu \mathrm{m}$. 
plasmas also occurred between the plasmalemma and basal lamina at the periphery of cells in both the principle and accessory salivary glands (Fig. 1D). Muscle cells, which abutted all of the salivary gland cell types, also contained spiroplasmas, usually located near the muscle fibers.

In salivary glands, spiroplasmas frequently were observed in pockets apparently formed by invagination of the cell plasmalemma (Fig. 3A through C). Some of these spiroplasmas appeared to be attached to the plasmalemma making up the pocket. The basal lamina surrounding salivary gland cells having spiroplasma-filled invaginations was always intact. In a few cases, spiroplasmas were found in the intercellular spaces between salivary gland cells. We never observed spiroplasmas adhering to the hemolymph side of the basal lamina of the salivary gland cells.

Cytopathology of $\boldsymbol{S}$. citri-infected leafhoppers. Spiroplasmas were observed in all four of the salivary gland samples examined and in two of four intestine samples from infected $C$. tenellus. They were not found in any of four salivary gland and four intestine samples from healthy leafhopper controls.

In healthy salivary glands, muscle cells were elongated in shape, contained a single nucleus and parallel layers of muscle fibers, and were located between the salivary gland cell basal lamina and plasmalemma (Fig. 5A). Muscle cells were situated outside the salivary gland cells; although they were sometimes partially embedded in the salivary gland cell cytoplasm, they were separated from it by the plasmalemmae of the two cells. Individual fibers were tightly aligned in discrete bundles and were attached at one end to the plasmalemma. In spiroplasma-infected salivary glands, muscle fibers appeared to have disintegrated at the point of attachment to the plasmalemma, and the remaining fibers were loosely aligned, no longer cohesive as in healthy samples (Fig. 5B).

In healthy intestines, muscle cells were situated outside of the epithelial cells between the epithelial basal plasmalemma and the basal lamina. Muscle fibers were intact and tightly aligned in healthy samples but were fragmented and loosely aligned in infected muscle cells. However, the disorganization was less extensive in intestinal muscle cells than in muscle cells of the salivary glands.

Salivary cell membrane components consistently appeared less distinctly in spiroplasma-infected samples compared with healthy ones. The salivary basal lamina of infected insects was less electron-dense and more diffuse than that of healthy leafhoppers. Although these effects caused membranes to appear less distinct, the plasmalemma of infected insects otherwise appeared normal. This same effect was observed in the membranes and basal lamina of infected midgut epithelial cells.

In infected salivary gland cells, spiroplasmas usually were found in membrane-bound vesicles (Fig. 6A); however, vesicles devoid of recognizable spiroplasmas occasionally were seen at the periphery of infected salivary gland cell types I and IV (Fig. 6B). These "empty" vesicles often were located close to other vesicles containing individual spiroplasmas or colonies of spiroplasmas and were approximately the same size as vesicles containing spiroplasmas. The spiroplasmas in these adjacent vesicles, although recognizable, often appeared to have poorly defined membranes (Fig. 6A).

In cell type III, irregular, dense matrices ( 0.6 to $1.7 \mu \mathrm{m}$ in diameter) often were found in the cytoplasm of infected samples (Fig. 7A through B). These matrices, which varied in electron density, contained fibrous material that resembled either membrane fragments or chromatin fibers. The matrices were heavily decorated with colloidal gold when immunolabeled with anti-S. citri antibodies (Fig. 7A) but were not labeled when the same tissue was probed with preimmune antiserum (Fig. 7B). Interestingly, such matrices were not seen in type III cells that contained large numbers of recognizable spiroplasmas.

In healthy salivary gland cells, the endoplasmic reticulum was intact and its membranous laminae were evenly aligned. Golgi bodies and secretory granules were intact and electron-dense, and cells contained numerous mitochondria. In the salivary gland cells of spiroplasma-infected leafhoppers, Golgi bodies, secretory granules, and mitochondria showed no apparent changes in size or morphology. In infected cells, however, the endoplasmic reticulum appeared disorganized (Figs. 4, 5B, 6B, and 7A). The endoplasmic reticulum was not recognizable as rough or smooth, because the laminae were not recognizable and ribosomes appeared to be randomly distributed throughout the cytoplasm.

\section{DISCUSSION}

Transmission of propagative phytopathogens by insect vectors is a complex process. The microbe may be a pathogen of the insect as well as of the plant, a factor that may influence the effectiveness of that insect both as a host and as a vector of the pathogen. Molecular interactions of the microbe and insect host at several locations in the insect's body are critical to the pathogen's traversal of the cellular barriers in the vector.
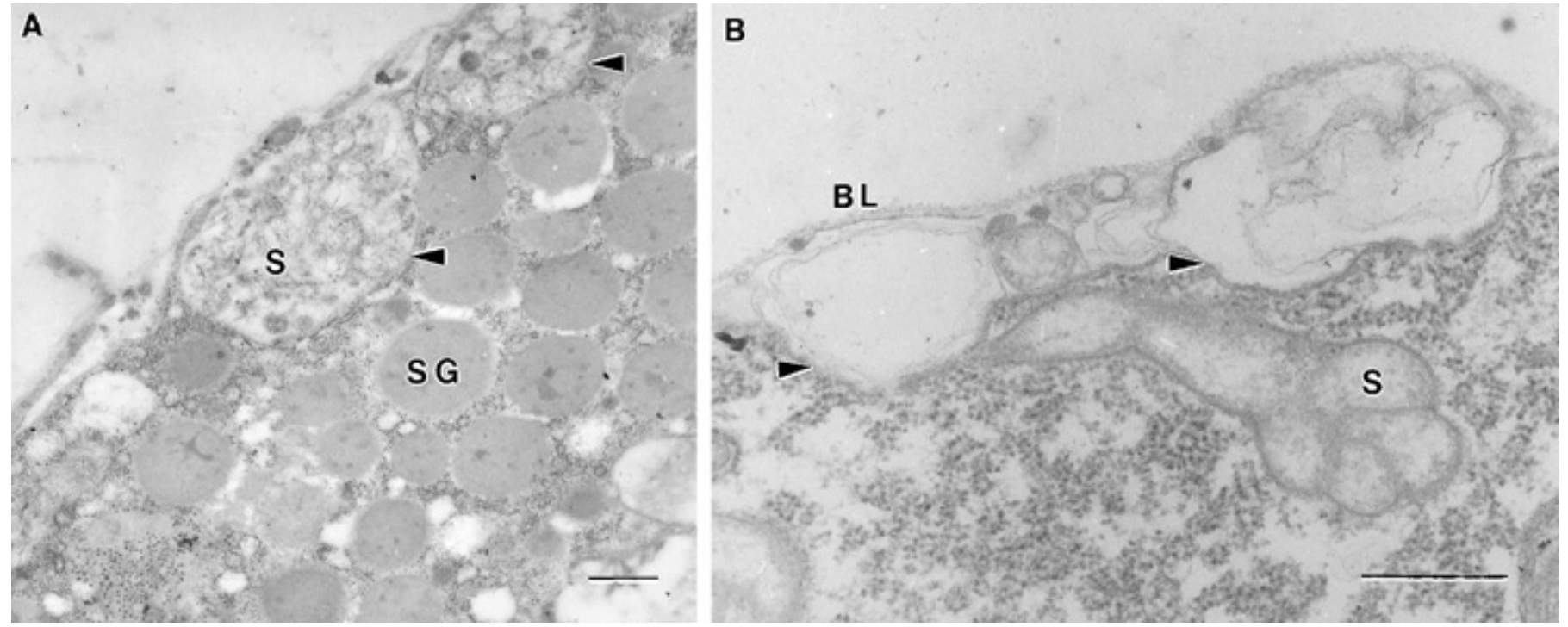

Fig. 6. Vesicles in Spiroplasma citri-infected salivary gland cells. A, Vesicles filled with recognizable spiroplasmas (arrows). B, Vesicles apparently devoid of spiroplasmas on the periphery of an infected salivary gland cell (arrows). $\mathrm{S}=$ spiroplasma, $\mathrm{SG}=$ secretory granule, $\mathrm{BL}=$ basal lamina. $\mathrm{Bars}=0.5 \mu \mathrm{m}$. 
Although several previous reports $(1,8,12,18)$ had identified the location of spiroplasmas within insect vectors, details on the relationship between the pathogen and specific insect cells were incomplete. This was due, in part, to a lack of descriptive information regarding the number and morphology of specific cell types in leafhopper tissues. Toward this goal, Wayadande et al. (19) identified eight different cell types in the principal salivary glands of the beet leafhopper. Each cell type has distinctive characteristics such as size, internal complexity, presence and electron density of secretory granules, and the presence or absence of microvilli in the canaliculi. In this investigation, we sought to expand our understanding of the location, mechanism of transmission, and cytopathology of the plant pathogen, $S$. citri, within its vector, the beet leafhopper, C. tenellus. Our work included a survey of each of the salivary gland cell types as well as the midgut epithelial cells.

Because $S$. citri cells lose their helicity after they invade insect tissues, becoming pleomorphic, it is sometimes difficult to recognize them in electron micrographs. In early stages of this study, immunolabeling was used to positively identify spiroplasmas in the insect tissues and to learn their distinguishing features. Later, spiroplasmas were recognized by their size, the presence of a trilaminar plasmalemma, and the presence of reticulated DNA-like strands in the cytoplasm. This characteristic spiroplasma morphology has been reported elsewhere $(8,12,17)$.

The method or methods of spiroplasma entry into vector insect alimentary and salivary cells have not been conclusively determined. Mowry (15) investigated the interactions of $S$. citri and cells of the experimental vector, $M$. fascifrons, concluding that $S$. citri movement into the cells of this insect occurs by receptor-mediated endocytosis. Liu (11) reported that $S$. citri cells traverse the gut wall of $C$. tenellus via the endoplasmic reticulum; however, no electron micrographs were provided. Alivizatos and Markham (1) found spiroplasmas only at the periphery of leafhopper salivary gland cells, between the basal lamina and plasmalemma, and not within the cell cytoplasm. Markham (13) suggested that this spiroplasma traverses the salivary glands of $C$. tenellus by moving between the cells (diacytosis) rather than through them. In gut tissues, Lefol et al. (10) found FD phytoplasmas inside cells and in junctions between cells and concluded that this phytoplasma traversed host tissues by both endocytosis and diacytosis.
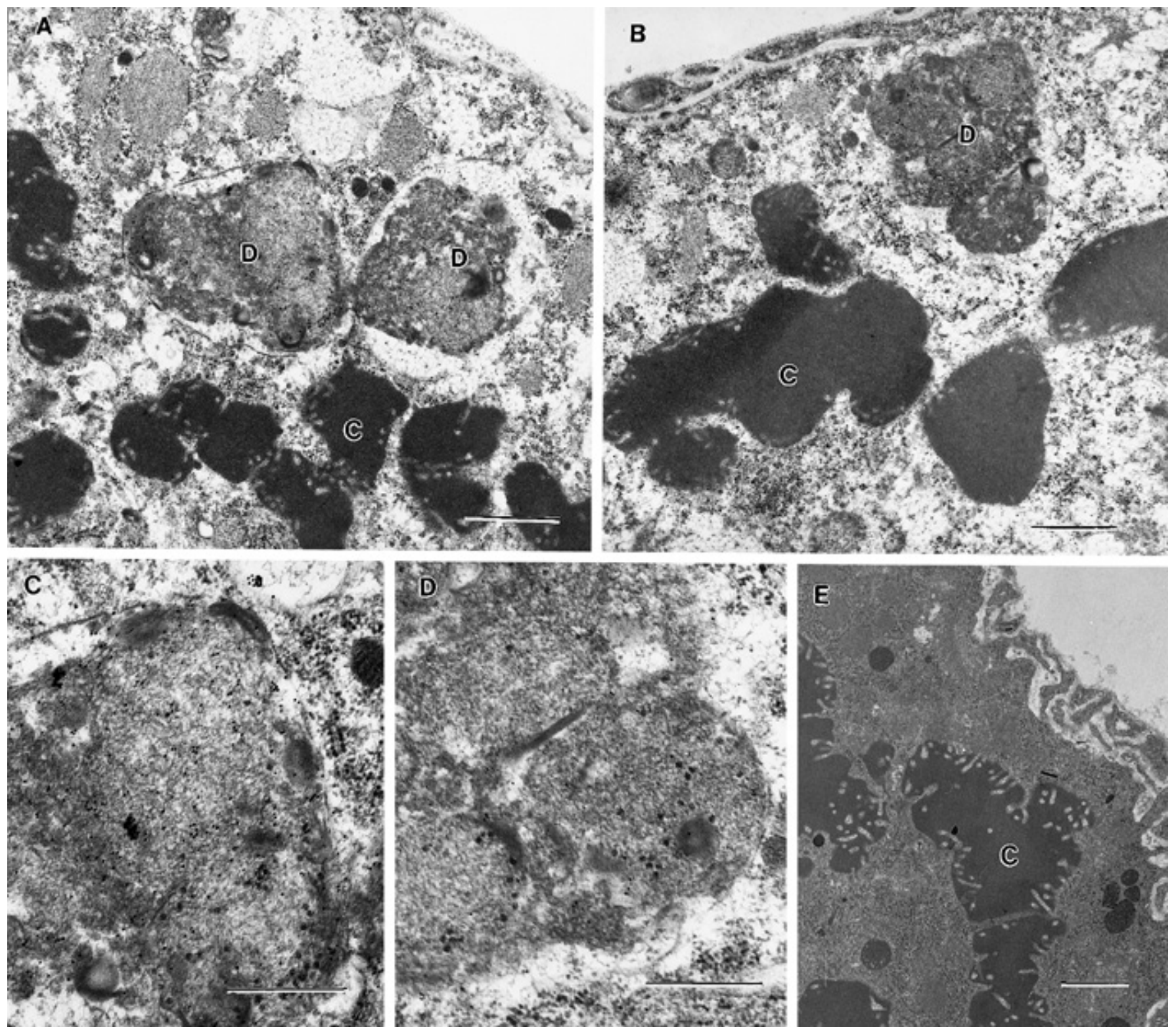

Fig. 7. Dense matrices found in Spiroplasma citri-infected type III salivary gland cells. A, Low magnification showing structures of infected cell treated with BR3-3X antiserum and goat anti-rabbit 10-nm gold particles (GAR-gold). Bar $=1 \mu \mathrm{m}$. B, Low magnification showing structures of infected cell treated with preimmune serum and GAR-gold. Bar $=1 \mu \mathrm{m}$. C, High magnification of A showing specific decoration of dense matrix. Bar $=0.5 \mu \mathrm{m}$. D, High magnification of $\mathbf{B}$ showing nonspecific decoration. Bar $=0.5 \mu \mathrm{m}$. E, Healthy Circulifer tenellus type III salivary gland cell. $\mathrm{D}=$ dense matrix, $\mathrm{C}=$ canaliculus. Bar $=1 \mu \mathrm{m}$. 
A major goal of this study was to reexamine the mechanism of $S$. citri entry into vector cells. In general, microbes and other foreign bodies can be taken up by host cells by several methods. Phagocytosis is a process in which the folds of host cell membranes extend outward, surrounding and engulfing the pathogens, followed by uptake into the cell cytoplasm. Endocytosis is the entry of pathogens into host cell by invagination of the plasmalemma. Both phagocytosis and endocytosis result in the release of microbe-containing membrane-bound vesicles in the cytoplasm. Wayadande and Fletcher (21) found $S$. citri apparently invaginated in the plasmalemmae of two leafhopper cell lines, but membrane-bound vesicles were rarely observed. In this study, spiroplasmas were commonly found in membrane-bound vesicles, both in the interior and at the outer edges of $C$. tenellus cells in both the salivary glands and midgut epithelia. In electron micrographs, it is difficult to distinguish between vesicles formed by phagocytosis or endocytosis; however, in this work, spiroplasma colonies were observed in membranous pockets apparently invaginated from the plasmalemma of $S$. citri-infected salivary gland cells. Spiroplasma-containing membrane-bound vesicles apparently were formed as these pockets pinched off from the plasmalemma. In one micrograph (Fig. 3A), fingerlike regions of an epithelial cell, located between the spiroplasma-filled vesicle and the basal lamina, might be interpreted as closing around the enveloped spiroplasmas. We believe that this was occurring during the final stage of an endocytotic event, because plasmalemma-bound cytoplasmic extensions into the space between the basal lamina and plasmalemma were never seen. In this study, spiroplasmas occasionally were seen between adjacent cells of the salivary glands but not between cells of the gut epithelia. The observations reported here suggest that spiroplasma invasion of the insect salivary glands and intestines occurs primarily by endocytosis. However, it is possible that spiroplasmas, like FD phytoplasmas, can traverse host-cell barriers in more than one way. If spiroplasmas occasionally observed at cell junctions were entering the salivary glands by diacytosis, this process must have been far less frequent than that of endocytosis. It is difficult to envision how spiroplasmas in this location would be able to reach the salivary duct lumen, because cuticle deposition in the duct occurs internally within the salivary gland mass (19). The fact that several spiroplasmas were found inside canaliculi is consistent with the interpretation that spiroplasmas move into the salivary ducts via the canaliculi in the cytoplasm of the host cell. Therefore, our data are most consistent with movement via receptor-mediated endocytosis.

Another unresolved issue is how spiroplasmas cross the basal lamina, both at the gut and salivary gland interface with the hemocoel. The basal lamina has been reported to consist of collagenlike particles embedded in a polysaccharide matrix arranged in a lattice structure that permits enlargement of the tissue it is surrounding (7). In a previous study, we showed that $C$. tenellus basal lamina around the gut consists of two layers, both of which are amorphous without any obvious pores or lattice structures (19). The chemical composition of the basal lamina of leafhoppers is unknown but presumed to be similar to that of other insects. In this study, we never observed disrupted basal lamina in areas of spiroplasma colonization of gut or salivary gland. How did the spiroplasmas that infected these cells cross the basal lamina? It is possible that small pores or tears in the basal lamina existed but were not apparent in the plane of section examined. Pleomorphic spiroplasmas may have opportunistically squeezed through the gut basal lamina to gain access to the hemolymph or through the salivary gland basal lamina to reach the underlying cell plasmalemma. This question may remain unanswered until spiroplasmas are observed interacting directly with the basal lamina.

In infected leafhopper salivary glands, cell type III contained dense material that superficially resembled some viral inclusion bodies. That this material was strongly decorated when immunolabeled with anti-S. citri antibody-colloidal gold suggested that it might consist of degraded spiroplasma cells. It is possible that the type III cells might have macrophagic activity, allowing them to trap and digest spiroplasmas, forming these dense matrices. Interestingly, these matrices were not found in sections of cell type III that contained numerous membrane-bound spiroplasma-containing vesicles, suggesting that infection may cause loss of vital cell functions or that macrophagic activity could not keep pace with the colonization by spiroplasmas.

The terms "muscle cell" and "muscle fiber" have not always been clearly distinguished in previous reports of spiroplasma localization in insect hosts. The muscle cell contains a nucleus and other membrane-bound eukaryotic organelles as well as striated muscle fibers composed of individual myofilaments. Phillips and Humphery-Smith (17) reported that $S$. taiwanense-infected mosquitoes showed rather severe cytopathological symptoms, including muscular necrosis and that spiroplasma replication in the thoracic flight muscles led to the loss of flight capacity. In the present study, disorganization of $C$. tenellus muscle fibers was observed in both midgut and salivary gland muscle cells, but severe muscle tissue and organ deformation like that observed in S. taiwanenseinfected mosquitoes (17) was not observed in our work nor were cells severely compromised ultrastructurally. These findings may reflect the degree of coevolution of pathogen and vector; spiroplasmas may become less pathogenic to their vector over time (11).

$S$. citri has been reported to cause premature death and reduced fecundity in $C$. tenellus (11). These detrimental effects may be the result of several factors, including competition between the host cell and pathogen for nutrients and toxicity of microbial byproducts. The cytopathological changes observed in this study, including the disorganization of muscle fibers and endoplasmic reticulum and colonization of spiroplasmas in the cell cytoplasm of infected leafhoppers, may be important factors as well.

\section{ACKNOWLEDGMENTS}

Approved for publication by the director of the Oklahoma Agricultural Experiment Station. This work was partially funded by USDA-NRI grant 92-37303-7802. We thank P. Doss for technical assistance and L. Littlefield, E. Blouin, and M. Palmer for critical review of the manuscript.

\section{LITERATURE CITED}

1. Alivizatos, A. S., and Markham, P. G. 1986. Acquisition and transmission of corn stunt spiroplasma by its leafhopper vector, Dalbulus maidis. Ann. Appl. Biol. 108:535-544.

2. Chen, T. A., and Davis, R. E. 1979. Cultivation of spiroplasmas. Pages 65-79 in: The Mycoplasmas, vol. 3. R. F. Whitcomb and J. G. Tully, eds. Academic Press, New York.

3. Ebbert, M. A., and Nault, L. R. 1994. Improved overwintering ability in Dalbulus maidis (Homoptera: Cicadellidae) vectors infected with Spiroplasma kunkelii (Mycoplasmatales: Spiroplasmataceae). Environ. Entomol. 23:634-644.

4. Fletcher, J., Schultz, G. A., Davis, R. E., Eastman, C. E., and Goodman, R. E. 1981. Brittle root disease of horseradish: Evidence for an etiological role of Spiroplasma citri. Phytopathology 71:1073-1080.

5. Gildow, F. E. 1993. Evidence for receptor-mediated endocytosis regulating luteovirus acquisition by aphids. Phytopathology 83:270-277.

6. Gildow, F. E., and Gray, S. M. 1993. The aphid salivary gland basal lamina as a selective barrier associated with vector specific transmission of barley yellow dwarf luteoviruses. Phytopathology 83:1293-1302.

7. Gouranton, J. 1970. Etude d'une lame basale presentant une structure d'un type nouveau. J. Microsc. (Paris) 9:1029-1040.

8. Granados, R. R. 1969. Electron microscopy of plants and insect vectors infected with the corn stunt disease agent. Contrib. Boyce Thompson Inst. 24:173-187.

9. Hackett, K. J., and Clark, T. B. 1989. Ecology of spiroplasmas. Pages 113-200 in: The Mycoplasmas, vol. 5. R. F. Whitcomb and J. G. Tully, eds. Academic Press, San Diego, CA.

10. Lefol, C., Lherminier, J., Boudon-Padieu, E., Larrue, J., Louis, C., and Caudwell, A. 1994. Propagation of flavenscence doreé MLO in the leafhopper vector, Euscelidius variegatus. J. Invertebr. Pathol. 63:285-293.

11. Liu, H. Y. 1981. The transmission, multiplication and electron microscopic examination of Spiroplasma citri in its vector, Circulifer tenellus. 
Ph.D. dissertation. University of California, Riverside.

12. Liu, H. Y., Gumph, D. J., Oldfield, G. N., and Calavan, E. C. 1983. The relationship of Spiroplasma citri and Circulifer tenellus. Phytopathology 73:585-590.

13. Markham, P. G. 1983. Spiroplasmas in leafhoppers: A review. Yale J. Biol. Med. 56:745-751.

14. Markham, P. G., Townsend, R., Bar-Joseph, M., Daniels, M. J., and Meddins, B. M. 1974. Spiroplasmas are the causal agents of citrus littleleaf disease. Ann. Appl. Biol. 78:49-57.

15. Mowry, T. 1986. Mechanisms of and barriers to Spiroplasma citri infection of Macrosteles fascifrons (Stal). Ph.D. dissertation. Michigan State University, East Lansing.

16. O'Hayer, K. W., Schultz, G. A., Eastman, C. E., Fletcher, J, and Goodman, R. M., 1983. Transmission of Spiroplasma citri by the aster leafhopper, Macrosteles fascifrons (Homoptera: cicadellidae). Ann. Appl. Biol. 102: 311-318.

17. Phillips, R. N., and Humphery-Smith, I. 1995. The histopathology of experimentally induced infections of Spiroplasma taiwanense (class: Mollicutes) in Anopheles stephensi mosquitoes. J. Invertebr. Pathol. 66:185-195.

18. Townsend, R., Markham, P. G., and Plaskitt, K. A. 1977. Multiplication and morphology of Spiroplasma citri in the leafhopper, Euscelis plebejus. Ann. Appl. Biol. 87:307-313.

19. Wayadande, A. C., Baker, G. R., and Fletcher, J. 1997. Comparative ultrastructure of the salivary glands of two phytopathogen vectors, the beet leafhopper, Circulifer tenellus, and the corn leafhopper, Dalbulus maidis (Homoptera: Cicadellidae). Int. J. Morphol. Embryol. 26:113110.

20. Wayadande, A. C., and Fletcher, J. 1995. Transmission of Spiroplasma citri lines and their ability to cross gut and salivary gland barriers within the leafhopper vector, Circulifer tenellus (Homoptera: cicadellidae). Phytopathology 85:1256-1259.

21. Wayadande, A. C., and Fletcher, J. 1998. Development and use of an established cell line of the leafhopper Circulifer tenellus to characterize Spiroplasma citri-vector interactions. J. Invertebr. Pathol. 72:126-131.

22. Westcot, D., Ullman, D. E., Sherwood, J. L., Cantone, F. A., and German, T. L. 1993. Rapid fixation and embedding method for immunocytochemical studies of tomato spotted wilt tospovirus (TSWV) in plant and insect tissues. Microsc. Res. Technol. 24:514-520.

23. Whitcomb, R. F., Tully, J. G., Bove, J. M., and Saglio, P. 1973. Spiroplasmas and acholeplasmas: Multiplication in insects. Science 182:1251-1253. 